\title{
BIOCHEMICAL EFFECTS OF MATURED STEM EXTRACT OF OPUNTIA DILLENII IN MALE WISTAR RATS
}

\author{
Uche C. Njoku, \\ Benjamin A. Amadi, \\ Peter U. Amadi, \\ Onyebuchi E. Ezendiokwere, \\ Idongesit E. Archibong
}

Department of Biochemistry, University of Port Harcourt, Choba,

Nigeria

\begin{abstract}
Summary
The effect of aqueous matured stem extract of Opuntia dillenii on selected biochemical parameters in Male Wistar rats was explored. Standard analytical methods were applied. Forty Wistar rats $(80-100 \mathrm{~g})$ were used in the animal studies, separated into four groups. The control group was solely administered normal feed and saline, group I was administered $100 \mathrm{mgkg}^{-1}$ of the extract, group II received $300 \mathrm{mgkg}^{-1}$ of the extract and group III received $500 \mathrm{mg} / \mathrm{kg}^{-1}$ of the extract. A significant increase $(p<0.05)$ in the activities of alanine aminotransferase (ALT) and alkaline phosphatase was observed in group II and III rats, as compared with the controls. A significant decrease in urea and creatinine concentrations was found only in group III rats against the controls. Also, a significant $(\mathrm{p}<0.05)$ decrease in triglyceride, total cholesterol, and low density lipoprotein (LDL)cholesterol was seen in group II and group III rats when compared with the control. The hematological evaluation revealed a significant $(\mathrm{p}<0.05)$ decrease in red blood cell and hemoglobin levels in group III rats when compared with the control. The findings showed both beneficial and toxicological effects of the plant. Hence, for optimal therapeutic benefits, a further toxicological survey could still be carried out perhaps at higher doses.
\end{abstract}

Key words: Opuntia dillenii; biochemical parameters; toxicity; hemoglobin; lipid profile

\section{Introduction}

It is without doubts that recently, the world's increasing interests in the health benefits of foods have transcended basic nutritional benefits of foodstuff to disease prevention. The World Health Organization recognizes the use of natural plant products as cheaper and more viable treatment for diseases. Opuntia dillenii are members of the Cactaceae family used as forage for livestock, and it is widely spread in Africa and most countries in North, Central and South America [1]. Mature stems of Opuntia dillenil have been known as rich in secondary metabolites of plants such as flavonoids, alkaloids, and saponins [2-4] and also, calcium, magnesium, phosphorus, vitamin $\mathrm{A}$ and vitamin $\mathrm{B}_{12}[5]$.

In spite of all these benefits, the species Opuntia dillenii (Ker-Gawl) Haw under scrutiny can be classified 
as an underutilized nutritional and medicinal plant in Western Africa and especially, in Nigeria [2]. Some studies have demonstrated its analgesic, anti-ulcerogenic, anti-inflammatory and radical scavenging activities [6-8].

Consequently, clinical pharmacological curiosity in the efficacy, safety and otherwise of the biologically active compounds present in the genus Opuntia has surged recently because of the consciousness that most individuals adopt self-medication using this pant [9].

The wrong use of the therapeutic effect of this plant may result in severe alterations, and for this reason, the experimental investigation of the risks and benefits associated with these therapies are appropriate.

\section{Materials and Methods}

\section{Sample collection}

Fresh matured stems of Opuntia dillenii were obtained from farmland in Umuanuma Nguru in Aboh Mbaise Local Government Area of Imo State. The plant was grown at the herbarium unit of the Department of Plant Science and Biotechnology, University of Port Harcourt Choba.

\section{Sample Preparation}

The stems were thoroughly washed, and the spines were manually removed with clean knives, air-dried and pulverized into a powder with a well-washed manual grinder and was stored using airtight sample bottles before analysis.

\section{Preparation of Extract}

The aqueous extraction was done using the cold-water method. Precisely $400 \mathrm{~g}$ of the dried powdered sample was soaked in $1.5 \mathrm{~L}$ of distilled water in a conical flask and was vigorously shaken for 2 mins and left for $24 \mathrm{hrs}$. The mixture was filtered, and the filtrates were concentrated using rotary evaporator at $50^{\circ} \mathrm{C}$ and evaporated to dryness in an evaporating dish with a thermostat water-bath heater at $50^{\circ} \mathrm{C}$. The stem extract was removed from the evaporating dish using a spatula and collected into a dry sterile container. Precisely $16 \mathrm{~g}$ and $24 \mathrm{~g}$ were weighed from the stem extract and dissolved in separate flasks containing $77 \mathrm{ml}$ of distilled water.

\section{Experimental and Research Design}

Forty Male Wistar rats weighing (80-100 g) were acquired from the animal house of the Department of Biochemistry, University of Port Harcourt, Choba, Nigeria. The experimental animals were housed for seven days in standard cages for acclimatization. The rats were kept according to the stipulations of National Institute of Health (NIH) Guide for Care and Use of Laboratory Animals [10]. The rats were divided into four groups of ten rats each, allocated as one control group and groups I, II and III. The experimental study lasted for twenty-eight (28) days, and the administration schedule was as follows:

- Controls: normal saline + feed + water;

- Group I: $100 \mathrm{mg} / \mathrm{kg}$ body weight of matured stems of Opuntia dillenii extract + feed + water; Group II: $300 \mathrm{mg} / \mathrm{kg}$ body weight of Opuntia dillenii extract + feed + water;

- Group III: $500 \mathrm{mg} / \mathrm{kg}$ body weight of Opuntia dillenii extract + feed + water.

The dosage of administration of the extract was according to the methods of Loro et al. (1999) [11] and Akacha et al. (2015) [12].

\section{Blood Sample Collection}

At the end of administration (28 days), the rats were anesthetized with diethyl ether and dissected. Blood was obtained via cardiac puncture into heparin sample bottles and Ethylene diamine tetraacetic acid (EDTA) anticoagulant tubes. Kidney and liver samples were collected for histological study. The blood samples were carefully labeled and centrifuged at $2000 \mathrm{rpm}$ for $10 \mathrm{mins}$ at $4^{\circ} \mathrm{C}$ to obtain plasma.

\section{Histological Assessment}

The liver and kidney tissues from control and test rats were fixed in $10 \%$ buffered formalin $(\mathrm{pH} 7.3)$ for 24 hours, dehydrated in a mounting grade of ethanol $(50 \%, 70 \%, 90 \%$ then absolute, twice) for 1 hour. To permit the tissue to be embedded in paraffin, clearing in xylene preceded paraffin wax for another 1 hour to remove water from the tissue. The tissue was sectioned at $5 \mu \mathrm{m}$ and stained with hematoxylin and eosin before examination with a light microscope (Brian SCI Coy). 


\section{Plasma Assay}

The plasma assays conducted were liver, kidney function test, and lipid profile. The concentration of alanine aminotransferase (ALT) was estimated by the method of [13] while alkaline phosphatase was determined as explored by [14]. Creatinine was estimated using the method described by [15]. Urea determination was conducted via the UreaseBerthlot method. Total cholesterol, triglyceride, and high-density lipoprotein cholesterol assessment was carried using Stein [16] method. Plasma low density lipoproteincholesterol (LDL-C) was evaluated using [17].

\section{Hematological Assessment}

Blood samples, stored in ethylene diamine tetraacetic acid (EDTA) anti-coagulant bottles, were assayed using BC 5300 Mindray Hematology Auto-Analyzer. They were blended, using a blood mixer. Blood stains were cleaned with cotton wool, and then a computer system and a hematology auto analyzer were powered. The information for each sample was keyed in according to their groups. The blood samples in the EDTA bottles were presented to the sample probe in the autoanalyzer one after the other for aspiration. The samples were analyzed by the autoanalyzer and the results were printed.

\section{Statistical Analysis}

Statistical packages of social science (SPSS) v.20.0 were used to analyze all the data obtained from this study. The results are presented as mean values $(\mathrm{M}) \pm$ SEM (Standard error of the mean). One-way with Turkey test was performed to assess significant differences between groups. The significance level was considered at $95 \%$ confidence level $(p<0.05)$.

\section{Results}

The outcome of ALT and alkaline phosphatase activities presented in Figure 1 and 2 in that order, showed significant $(\mathrm{p}<0.05)$ differences in the activities of these enzymes in groups II $(10.20 \pm 0.333$ and $424 \pm 6.009)$ and group III (16.20 \pm 0.881$)$ rats when compared with the

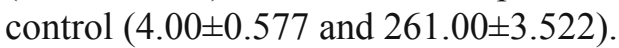

The observed decrease in urea and creatinine level (Figure 3 and 4) in group III $(4.00 \pm 0.115$ and $59.60 \pm 4.337$ ) rats against the control $(4.93 \pm 0.120$ and $95.00 \pm 1.732)$ respectively, was significant $(\mathrm{p}<0.05)$.

A significant decrease $(\mathrm{p}<0.05)$ was observed in the triglyceride, total cholesterol, and lowdensity lipoprotein cholesterol levels (Figures $5-7)$ in group II $(1.03 \pm 0.082,2.40 \pm 0.027$ and $0.96 \pm 0.121)$ and group III rats $(1.03 \pm 0.124$, $2.37 \pm 0.043$ and $0.80 \pm 0.058$ ), respectively, as compared with the controls $(1.60 \pm 0.105$, $3.00 \pm 0.012$ and $1.50 \pm 0.166$ ).

The hematological indices investigated exhibited significant increase $(\mathrm{p}<0.05)$ in white blood cells (WBC) values (Figure 8) in group II (13.46 \pm 0.025$)$ and III rats $(16.23 \pm 0.258)$ following the administration of the aqueous matured stem extract of Opuntia dillenii when compared with the control (5.45 \pm 0.534$)$.

Similarly, a significant decrease in red blood cells (RBCs) and haemoglobin (HGB) levels (Figure 9 and 10) was observed in group III rats (5.71 \pm 0.033 and $11.60 \pm 0.402)$ when compared with the control ( $7.38 \pm 0.031$ and $13.40 \pm 0.207)$.

\section{Discussion}

More often than not, hepatotoxic agents influence the release of certain enzymes such as aspartate aminotransferase, ALT, and alkaline phosphatase into the bloodstream as a consequence of damage to hepatocytes. ALT is mainly localized in the cytosol of hepatocytes [18]. Hence, ALT is a more specific liver enzyme for diagnostic use [19]. The observed increase in the activities of ALT and alkaline phosphatase could be a consequence of inflammation and disturbances of hepatocytes permeability.

Studies have established that alterations in the transport capacity of the hepatocytes attributable to hepatic injury lead to leakage of enzymes from cells to the bloodstream [20]. This outcome corroborates the findings of Saleem et al. (2005) [21] and Zouhir et al. (2015) [22] who reported similar increase in rats given methanolic and aqueous extract of Opuntia ficus indica and Opuntia dillenii, respectively, though not in line with Ncibi et al. (2008) [23] and Brahimi et al. (2011) [24].

Urea, produced by the liver and the main nitrogenous end product ofamino acid breakdown remains the most often utilized clinical indices for renal function evaluation [25].

Creatinine, a catabolic product of creatinine phosphate in muscles is regularly used to assess 
kidney function, and its relative production by the body mass is dependent on the mass of the muscle [26]. The observed decrease in urea and creatinine level in group (III) rats against the control suggests that aqueous matured stem extract of Opuntia dillenii does not confer nephrotoxic effects. El-said et al. (2011) [25] posited that significant decrease in blood urea and plasma concentrations in these rats might be attributed to the high ascorbic acid present in prickly pear (Opuntia fruit) peel.

Thus, this statement applies to matured stems of Opuntia dillenii as regards to the substantial amount of $\beta$-carotenoids and ascorbic acid present in the cladodes [5]. The observed decrease in urea and creatinine level in the present study corroborates the works of Korkmaz et al. (2009) [27].

The assessment of total cholesterol, triglyceride, high-density lipoproteins and lowdensity lipoproteins gives insight on the various disturbances of cholesterol and triglyceride levels associated with cardiovascular diseases [28]. A decrease that is significant $(\mathrm{p}<0.05)$ was observed in the triglyceride, total cholesterol, and low-density lipoprotein cholesterol (Figures 5-7) in group II and group III rats when compared with the control. The observed significant decrease supports the reports of [2931] Shapiro et al. (2002) [32] demonstrated in humans the anti-hyperlipidemic effect of Opuntia; they illustrated a significant decrease in Total cholesterol and LDL-cholesterol and a reduced platelet protein.

The significant decrease in the triglyceride, total cholesterol and low-density lipoprotein cholesterol observed in the present study suggest hypocholesteromic potentials of the matured stems of the studied plant and this could be attributed to the high saponin content (Table 1) in the matured stems of Opuntia dillenii [2].

The differences in the concentration of various compounds present in the blood of an organism could be an indication of certain disease conditions in such organisms [33]. The exhibited increase that is significant $(p<0.05)$ in WBC values in group II and III rats following the administration of the aqueous matured stem extract of Opuntia dillenii might be a consequence of the activation marker of the immune system and defense mechanism as a result of inflammation in the tissues [34].

The significant $(p<0.05)$ decrease in RBCs and HGB levels in group III rats when compared with the control suggest possible alterations in the balance between erythropoiesis and erythrocyte destruction as well as inhibition of hemoglobin synthesis [35].

The results of the histological assessment of the liver (Figure 11) revealed mild and severe intraparenchymal and periportal inflammation of the liver cells in group II and group III rats. An indication that increased extract concentration exerted severe inflammatory effects on the liver cells. This outcome suggests possible hepatotoxic potentials of the aqueous extract of Opuntia dillenii and it agrees with the reports of Saleem et al. (2005) [21] and Zouhir et al. (2015) [22].

The absence of hemorrhage between tubules, widening of the Bowman's capsule, spaces in the glomeruli as a result of contraction, severe dilatation of Bowman's capsule and glomeruli shrinkage, which are anomalies associated with renal damage (Figure 12) possibly indicates that the aqueous extract of Opuntia dillenii does not confer nephrotoxicity.

Table 1. Phytochemical composition of matured stems of Opuntia dillenii by Njoky et al. (2017) [2]

\begin{tabular}{ll}
\hline Component & $\begin{array}{l}\text { Concentration } \\
\mu \mathrm{g} / \mathrm{ml}\end{array}$ \\
\hline Anthocyanin & $0.04 \pm 0.02$ \\
\hline Oxalate & $1.07 \pm 0.01$ \\
\hline Tanin & $13.62 \pm 0.05$ \\
\hline Rutin & $12.41 \pm 0.26$ \\
\hline Phenol & $4.66 \pm 0.08$ \\
\hline Lunamarine & $34.43 \pm 0.35$ \\
\hline Saponin & $118.08 \pm 0.57$ \\
\hline Sapogenin & $11.88 \pm 0.09$ \\
\hline Ribalinidine & $3.75 \pm 0.09$ \\
\hline Phytate & $0.18 \pm 0.04$ \\
\hline Kaempferol & $7.90 \pm 0.06$ \\
\hline Catechin & $44.90 \pm 0.38$ \\
\hline
\end{tabular}


Njoku U, et al. Biochemical effects of matured stem extract of opuntia...

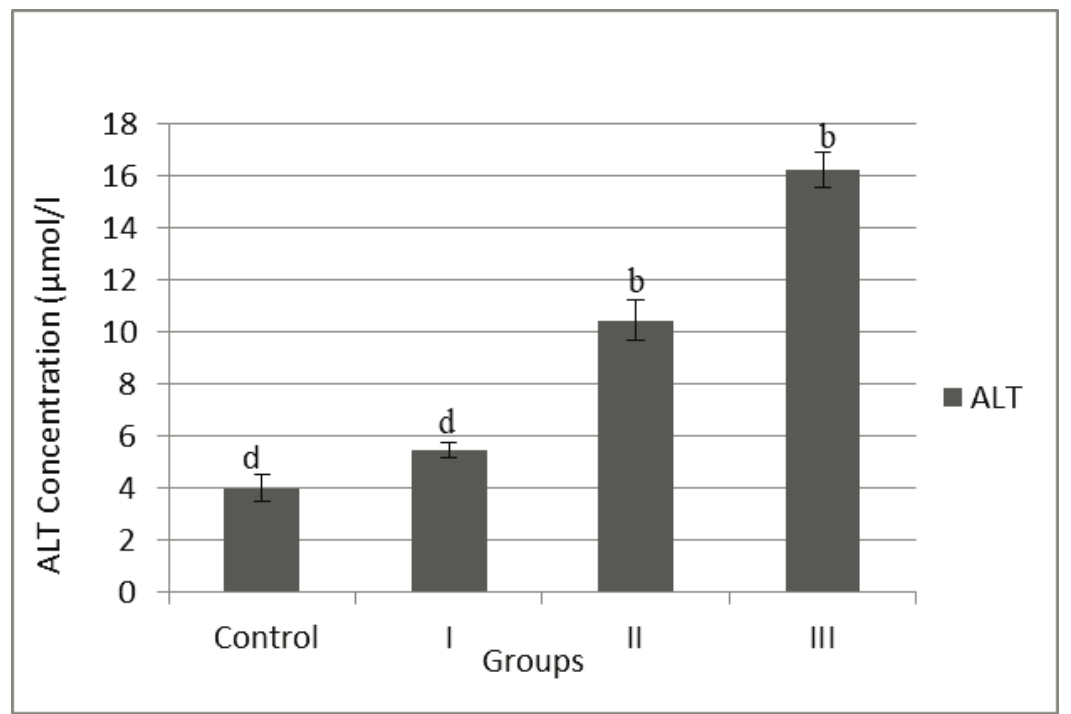

Figure 1. ALT concentration of rats. Bars with different letters of alphabets are statistically significant $(p<0.05)$

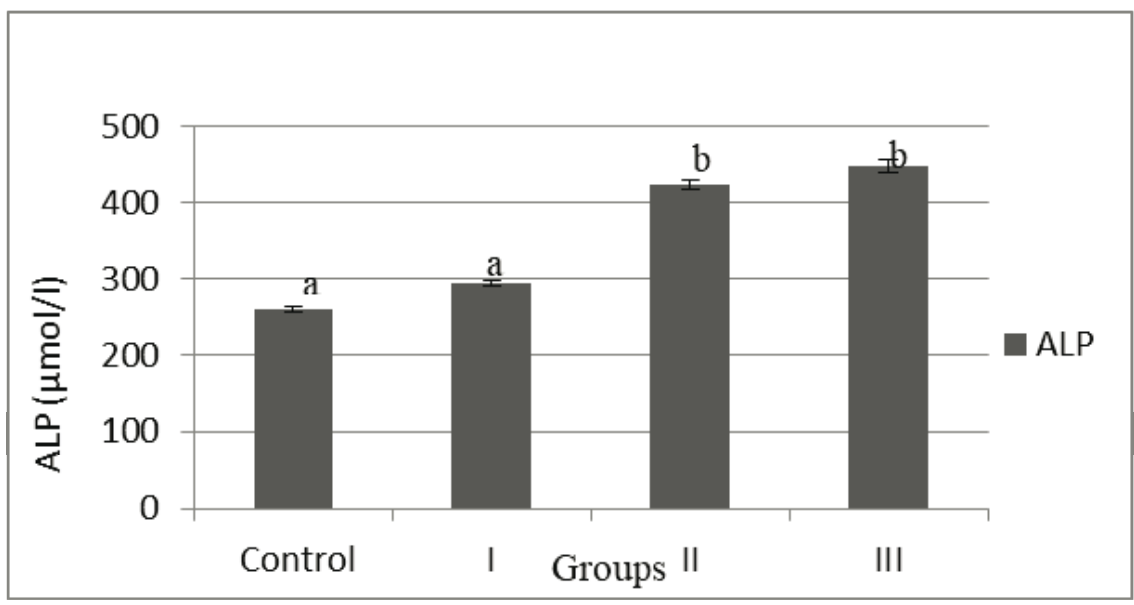

Figure 2. Alkaline phosphatase (ALP) concentration of rats. Bars with different letters of alphabets are statistically significant $(\mathrm{p}<0.05)$

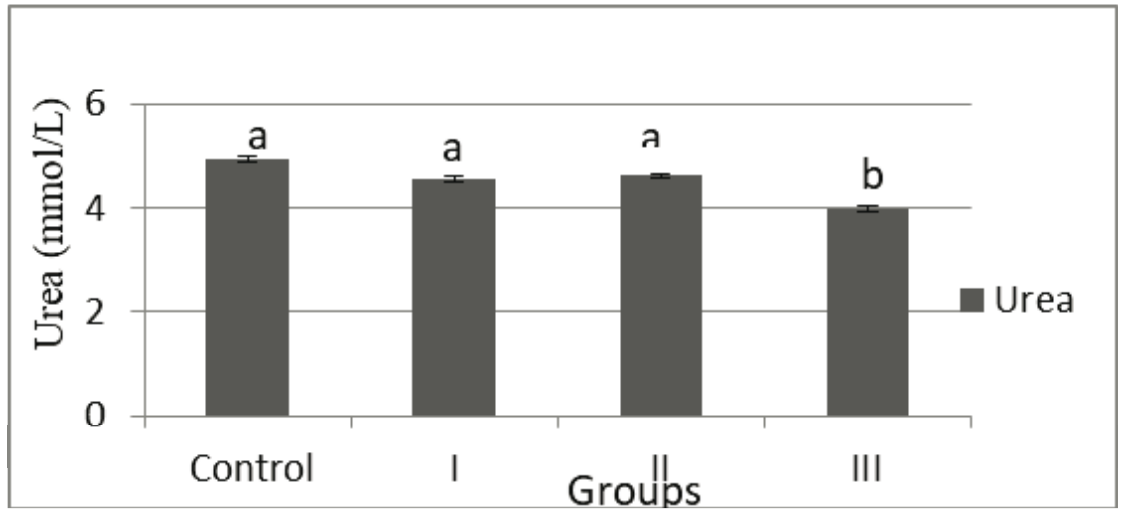

Figure 3. Urea level of rats. Bars with different letters of alphabets are statistically significant $(\mathrm{p}<0.05)$ 


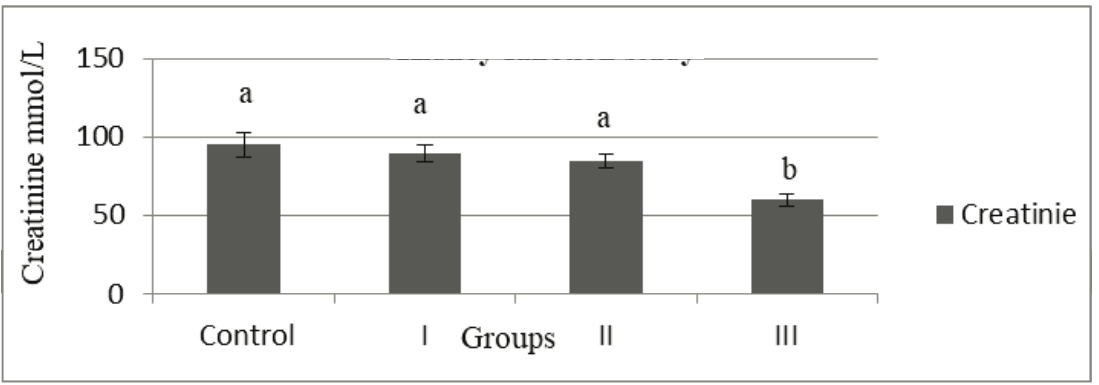

Figure 4. Creatinine level of rats. Bars with different letters of alphabets are statistically significant $(p<0.05)$

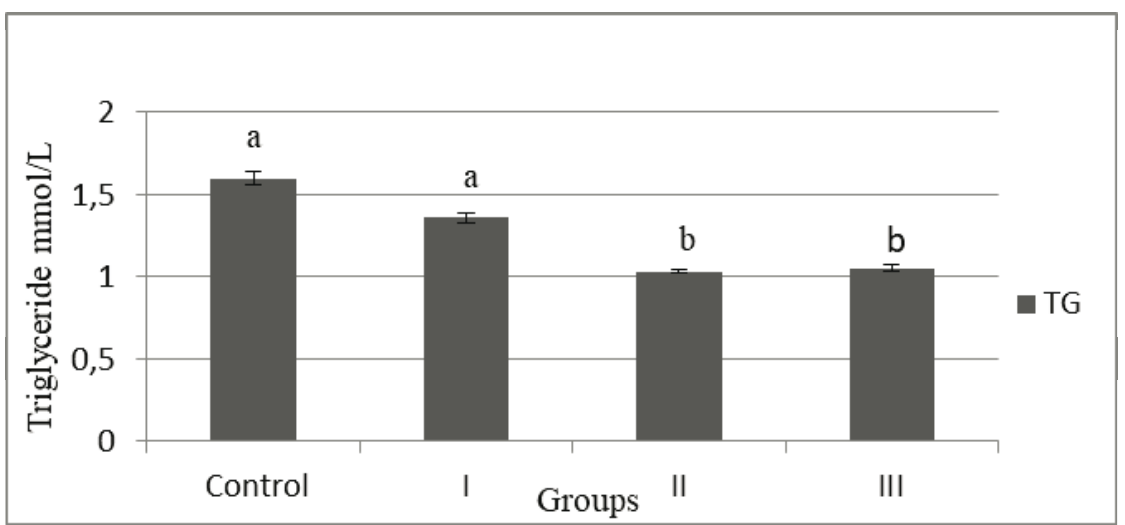

Figure 5. Triglyceride level of rats. Bars with different letters of alphabets are statistically significant $(\mathrm{p}<0.05)$

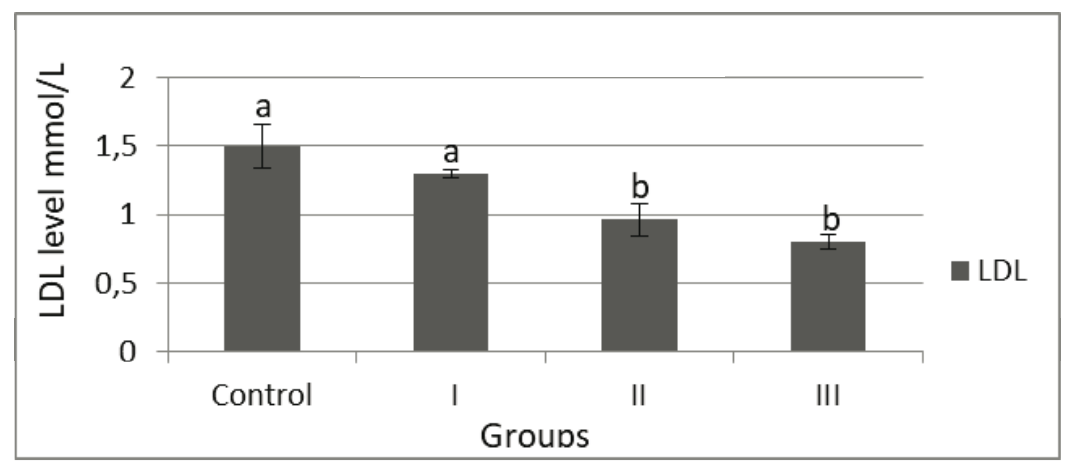

Figure 6. Total cholesterol (TC) level of rats. Bars with different letters of alphabets are statistically significant $(\mathrm{p}<0.05)$

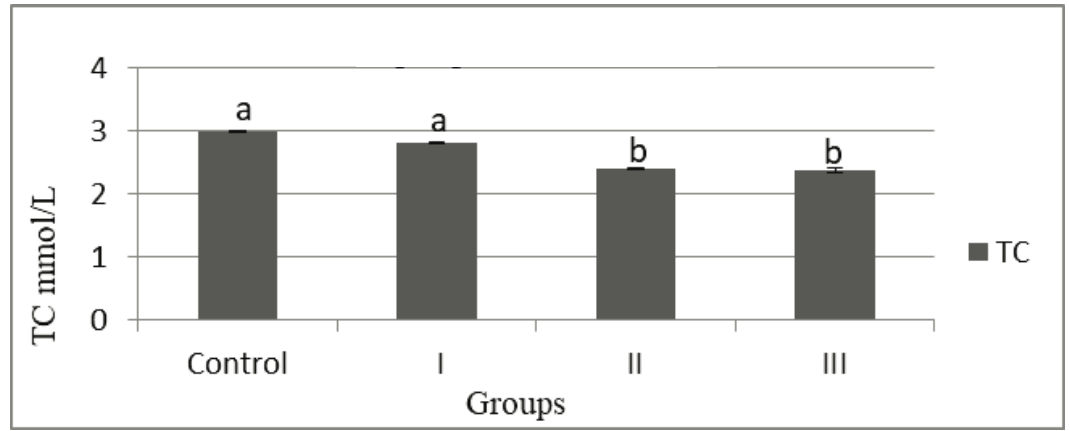

Figure 7. LDL-C level of rats. Bars with different letters of alphabets are statistically significant $(p<0.05)$ 


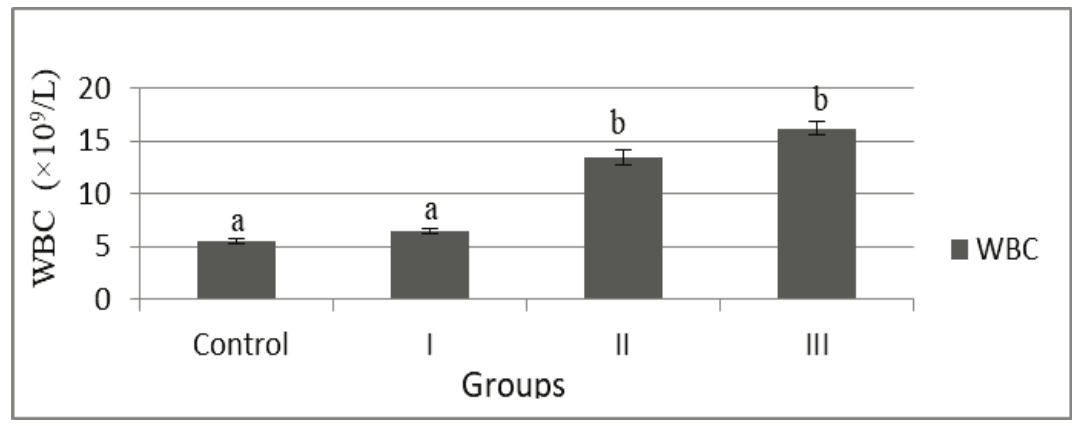

Figure 8. WBC level of rats. Bars with different letters of alphabets are statistically significant $(\mathrm{p}<0.05)$

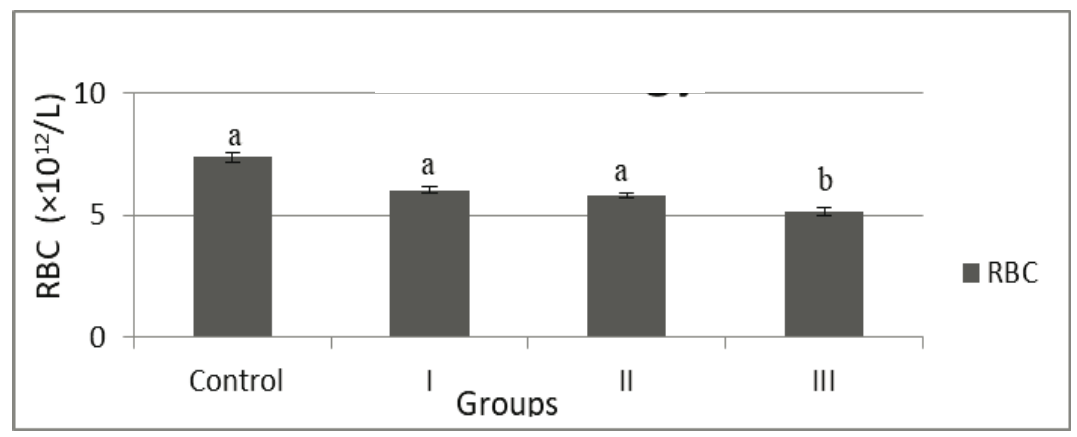

Figure 9. RBC level of rats. Bars with different letters of alphabets are statistically significant $(p<0.05)$

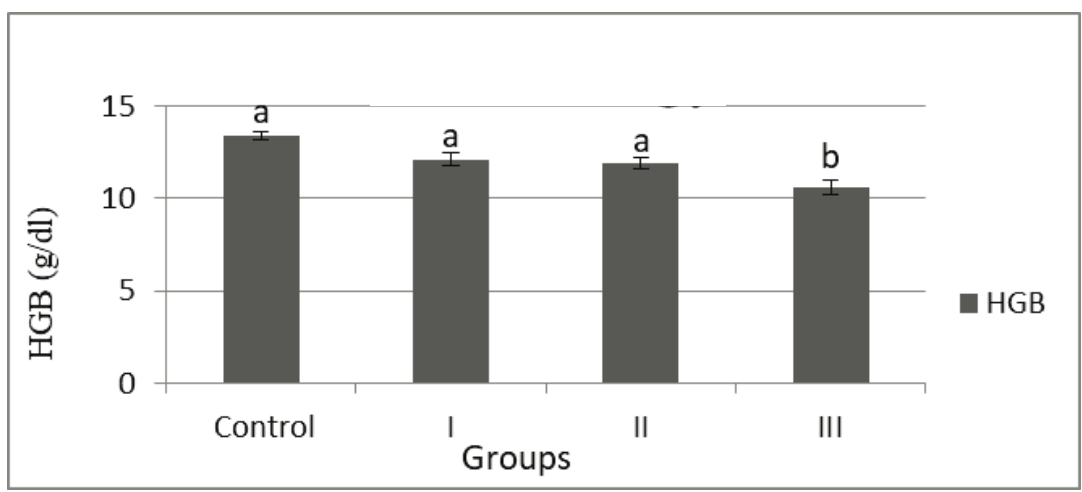

Figure 10. HGB level of rats. Bars with different letters of alphabets are statistically significant $(\mathrm{p}<0.05)$ 

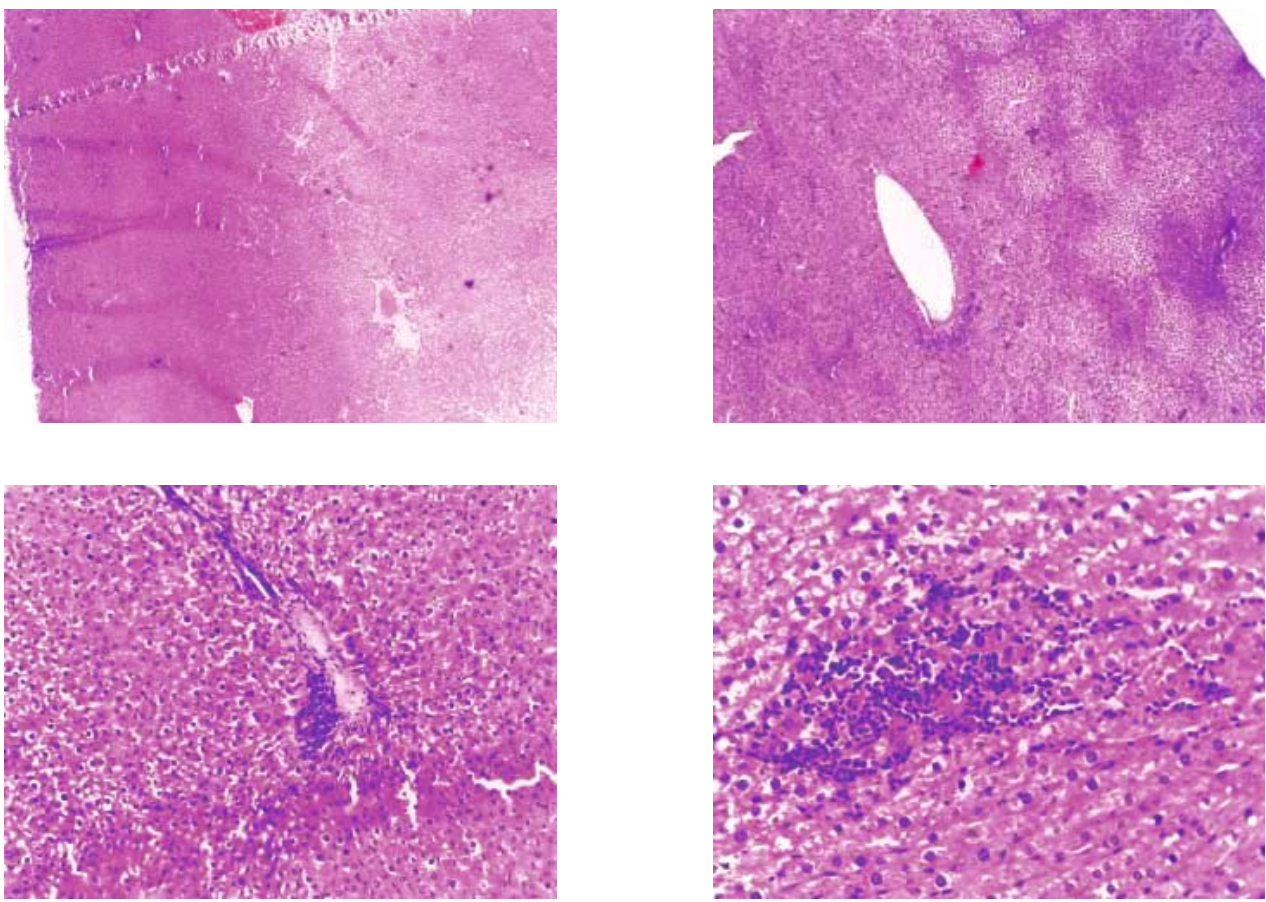

Figure 11. Microscopic view of the liver of control and the treated groups. *A: Control rats; \#B: Group I rats; §C: Group II rats; \#\#D: Group III rats. $\mathrm{MI}=$ mild inflammation, $\mathrm{SI}=$ severe inflammation
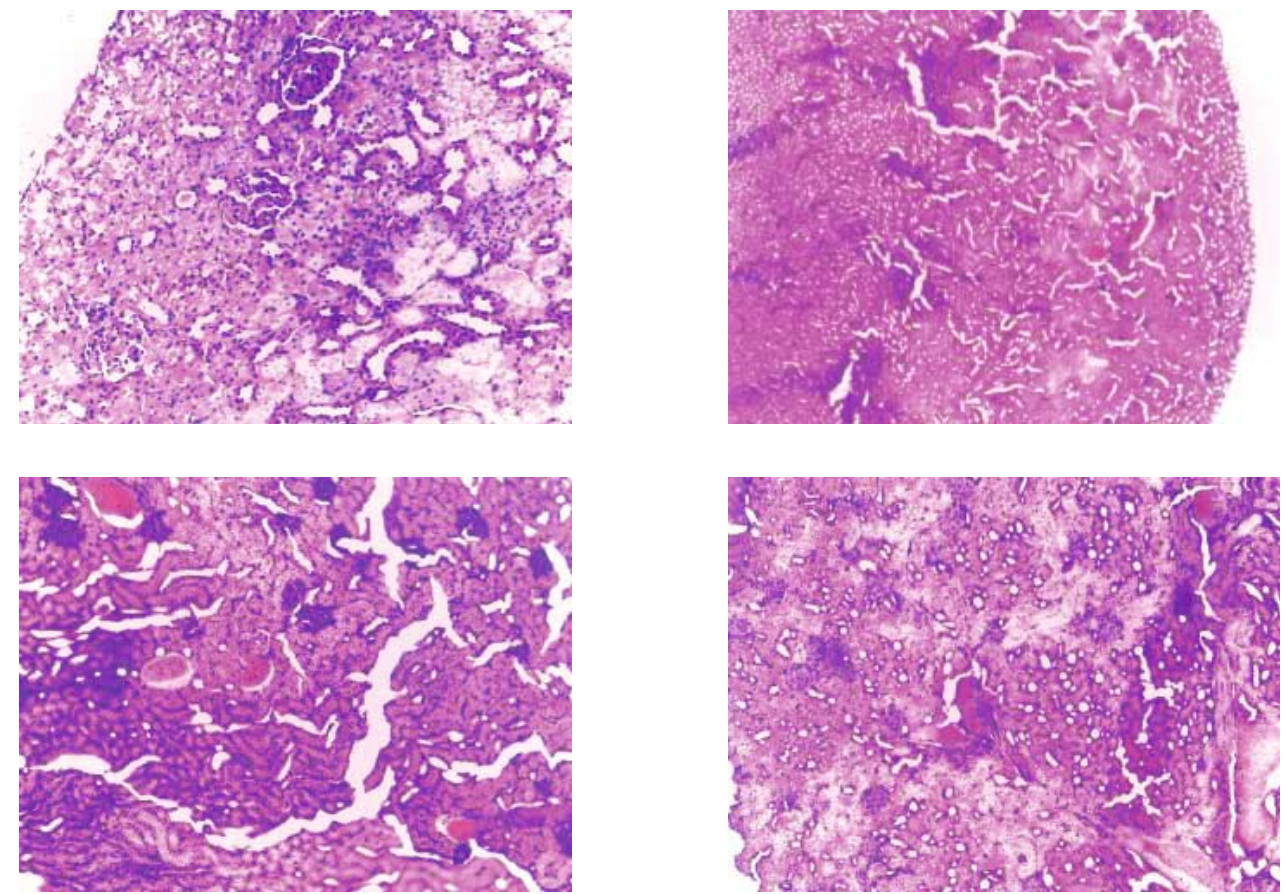

Figure 12. Microscopic view of the kidney of control and the treated groups 


\section{Conclusions}

The current study demonstrated the hypocholesteromic and nephroprotective properties of the matured stems of Opuntia dillenii. Nevertheless, these matured stems demonstrated a profound effect on hematological indices and possible hepatotoxic effects. Consequently, further toxicological investigations may still be carried out perhaps at higher doses for optimal therapeutic benefits.

\section{Competing Interests}

The authors declare that there is no conflict of interest regarding the publication of this paper.

\section{Acknowledgements}

The study was supported and privately sponsored by the authors.

\section{References}

1. Kaur M, Kaur A, Sharm R. Pharmacological actions of Opuntia ficus indica: a review. J Appl Pharma Sci. 2012;2(7):15-8.

2. Njoku UC, Amadi BA, Amadi PU. Chemical composition and physicochemical analysis of matured stems of Opuntia dillenii grown in Nigeria. J Food Sci Technol..2017;5(5):106-12.

3. Lee EH, Kim HJ, Song YS, Jin C, Lee KT, Cho $\mathrm{J}$, et al. Constituents of the stems and fruit of Opuntia ficus-indica var saboten. Arch Pharm Res. 2003;26(12):1018-23.

4. Jiang JQ, Ye WC, Liu YH, Chen Z, Min ZD, Lou FC. A new alkaloid from Opuntia vulgaris. Yao Xue Xue Bao. 2007;38(9):677-9.

5. Amadi BA, Njoku UC, Amadi PU, Agumuo EN, Ezendiokwere OE, Nwauche KT. Assessment of vitamins, protein quality and mineral bioavailability of matured stems of Opuntia dillenii grown in Nigeria. J Biosci Bioengi. 2017;5(3):47-54

6. Park EH, Kahng JH, Paek EA. Studies on the pharmacological actions of cactus: identification of is anti-inflammatory effect. Arch. Pharm. Res. 1998;21(1):30-4.

7. Kim JH, Park SM, Ha HJ, Moon CJ, Shin TK, Kim $\mathrm{JM}$, et al. Opuntia ficus-indica attenuates neuronal injury in in vitro and in vivo models of cerebral ischemia. J Ethnopharmacol. 2006;104(1-2):25762.

8. Galati EM, Monforte MT, Tripodo MM, d’Aquino
A, Mondello MM. Antiulcer activity of Opuntia ficus indica (L.) Mill. (Cactaceae) ultrastructural study. J Ethnopharmacol. 2001;76(1):1-9.

9. Osuna-Martinez U, Reyes-Esparza J, RodriguezFragoso L. Cactus (Opuntia ficus-indica): a review on its antioxidants properties and potential pharmacological use in chronic diseases. Nat Prod Chem Res. 2014;2(6):153-61.

10. National Institute Health. Guide for the care and use of laboratory animals. $8^{\text {th }} \mathrm{ed}$. Washington: The National Academies Press; 2011.

11. Loro JF, del-Rio I, Perez-Santana L. Preliminary studies of analgesic and anti-inflammatory properties of Opuntia dillenii aqueous fruit extract. J Ethnopharmacol. 1999;67(2):213-8.

12. Akacha A, Rebai T, Zourgui L, Amri M. Preventive effect of ethanolic extract of Cactus (Opuntia ficus-indica) cladodes on Methotrexate induced oxidative damage of the small intestine in Wistar rats. Arch Intern Med. 2015;7(6):1-7.

13. Reitman S, Frankel A. A colorimetric method for the determination of serum glutamic oxalacetic and glutamic pyruvic transaminases. Am J Clin Pathol. 1957;28 (1):56-63.

14. Wright PJ, Leathwood PD, Plummer DT. Enzymes in rat urine. alkaline phosphatase. Enzymologia. 1972;42(4):317-27.

15. Heinegard D, Tiderstrom G. Determination of serum creatinine by a direct colorimetric method. Clin Chim Acta. 1973;43(3):305-10.

16. Stein EA, Lipids, lipoproteins and apolipoproteins. In: Tietz NW, ed. Fundamentals of clinical chemistry. Philadelphia: WB Saunders; 1987; 470-9.

17. Friedeward WT, Levy RL, Fredrickson DS. Estimation of the concentration of low-density lipoprotein cholesterol in plasma, without use of the preparative ultracentrifuge. Clin Chem.1972;18(6):499-502.

18. Ben-Chioma AE, Tamuno-Emine DG, Jack AS. Effects of regular coke and coke zero on blood glucose, serum lipid profile and activities of serum aminotransferases in healthy human subjects. Int $\mathrm{J}$ Sci Res. 2015;4(11):1516-9.

19. Moss DW, Henderson AR. Enzymes. In: Tietz NW, ed. Fundamentals of clinical chemistry. Philadelphia: WB Saunders; 1996;283-335.

20. Fan G, Tang JJ, Bhadauria M, Nirala SK, Zhou $\mathrm{B}$, Yi L, et al. Resveratrol ameliorates carbon tetrachloride-induced acute liver injury in mice. Environ Toxicol Pharmacol..2009;28(3):350-6.

21. Saleem R, Ahmad M, Azmat A, Ahmaad Sl, Abidi L, Faizi S. Hypotensive activity, toxicology and histopathology of opuntioside-I and methanolic extract of Opuntia dillenii. Biol Pharm Bull. 2005;28(10):1844-51.

22. Djerrou Z, Maameri Z, Halmi S, Djaalab H, 
Riachi F, Benmaiza L, et al. Hepatoprotective effect of Opuntia ficus indica aqueous extract against carbon tetrachloride-induced toxicity in rats. Online J Biol Sci. 2015;15(2):36-41.

23. Ncibi S, Ben-Othman M, Akacha A, Krfi MN, Zourgui L. Opuntia ficus indica extract protects against chlorpyrifos-induced damage on mice liver. Food Chem Toxicol. 2008;46(2):797-802.

24. Brahmi D, Ayed Y, Bouaziz C, Zourgui L, Hassen W, Bacha H. Hepatoprotective effect of cactus extract against carcinogenicity of benzo(a) pyrene on liver of Balb/C mice. J Med Plant Res. 2011;5(18):4627-39.

25. El-Said NM, Nagib AI, Rahman ZA, Deraz SF. Chemical composition, nutritional value and protective effects of prickly pear peels on liver and kidney functions and cholesterol in rats. Funct Plant Sci Biotechnol. 2011;5(10):30-5.

26. Zuo Y, Wang C, Zhou J, Sachdeva A, Ruelos VC. Simultaneous determination of creatinine and uric acid in human urine by high-performance liquid chromatography. Anal Sci. 2008;24(12):1589-92.

27. Korkmaz A, Kolankaya D. The protective effects of ascorbic acid against renal ischemia-reperfusion injury in male rats. Ren Fail. 2009;31(1):36-43.

28. Sidhu D, Naugler C. Fasting time and lipid levels in a community based population: a cross sectional study. Arch Intern Med. 2012;172(22):1707-10.
29. Ennouri M, Fetoui H, Hammami M, Bourret E, Attia H, Zeghal N. Effects of diet supplementation with cactus pear seeds and oil on serum and liver lipid parameters in rats. Food Chem. 2007;101(1):248-53.

30. Eddouks M, Lemhadri A, Michel JB. Caraway and caper: potential anti-hyperglycaemic plants in diabetic rats. J Ethnopharmacol. 2004;94(1):1438.

31. Oguondo A, Efthimiou Y, Iliopoulos J, Sinzinger H. Prickly pear changes 111 indium-LDL and 111 indium-HDL platelet binding correlating to improvement of platelet function in hypercholesterolemia. J Prof Assoc Cactus. 2010; 12:67-9.

32. Shapiro K, Gong WC. Natural products used for diabetes. J Am Pharm Assoc. 2002;42(2):217-26.

33. Hoffbrand, AV, Petit, JE. Essential Hematology, $3^{\text {rd }}$ ed. Oxford: Blackwell Scientific; 1993.

34. Maturu, P, Reddy, VD, Padmavathi P, Varadacharyulu, N. Ethanol induced adaptive changes in blood for the pathological and toxicological effects of chronic ethanol consumption in humans. Exp Toxicol Pathol. 2012;64(7-8):697-703.

35. Emmanuel A, Majesty D, Benjamin A, Peter A, Princess U. Effect of caffeine on some selected biochemical parameters using rat model. Adv Biol Res. 2017 Jan; 1-9. 